bidrag fra et par onkologer, en psykolog, en bedemann og fra pårørende.

De 30 kapitlene er stort sett velskrevne, og selv om språket er dansk, så er det ikke vanskelig å få med seg fakta. En bred tematikk blir belyst: gravskikker, rettsmedisinsk obduksjon, bedemannens arbeid, palliativ behandling, hva vi dør av, samt arv og testamente. Redaktøren selv bidrar med bl.a. et kapittel som omhandler rettmedisinerens egne tanker om døden, et om samtale med pårørende og avskjed med den døde, og et eget kapittel om dødens etikk. Han har noe viktig å fortelle, og han skriver godt.

De tema som tas opp er aktuelle og det formidles mye faktakunnskap med tilhørende nyttige kommentarer fra forfatterne. Noe overlapping er vel ikke til å unngå. Selv om mye er felles i de skandinaviske land, er det åpenbart at boken først og fremst er nyttig i Danmark. Ikke bare pga. lovverk og forskrifter, men også grunnet seder og skikker i og utenfor institusjoner og i samfunnet generelt.

Hele boken preges av den rettsmedisinske bakgrunnen som flertallet av forfatterne har, men det er likevel ingen lærebok i rettsmedisin. Forfatterne forsøker å belyse mange fasetter rundt døden. Forventningene til en bok om døden er store. Kanskje et bidrag fra en allmennlege, kirurg, traumekirurg, sykepleier, jordmor, en hjemvendt soldat fra Afghanistan, en prest, en polititjenestemann/-kvinne eller en kriminaljournalist kunne vært på sin plass?

Layouten er litt traust, med få figurer/illustrasjoner. Litteraturreferansene er minimale og samlet på vel en side bakerst. Stikkordsregisteret er bra. Papiret er solid og velegnet for hyppige konsultasjoner.

Boken bidrar med viktig kunnskap og er relevant for helsefaglige utdanninger, men også for en rekke andre utdanningssøkende som skal arbeide med mennesker, liv og død.

Døden på dansk er greit nok, men jeg ville foretrekke et møte med døden mellom to permer på norsk.

\section{Livet som patient og ægtefælle}

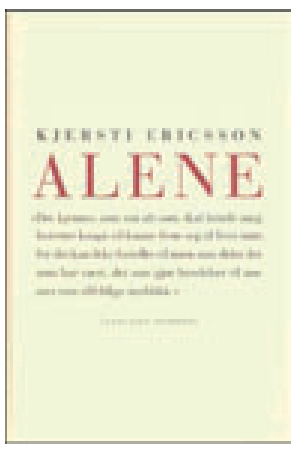

\author{
Kjersti Ericsson \\ Alene \\ 83 s. Oslo: Forlaget Oktober, 2011. \\ Pris NOK 159 \\ ISBN 978-82-495-0849-5
}

Sundhedsvæsener har behov for at aftabuere håbets nødvendighed samt døden, sorgen og tabet, og overføre mere viden og empati i hverdagens faglige sammenhænge.

Perspektivet for empati er nu i Norge belyst i selvoplevet, men også kunstnerisk, form af forfatter og kriminolog Kjersti Ericsson (f. 1944), som reaktion på tabet af ægtefællen et år forinden.

Hun skildrer forløbet af ægtefællens mavesækcancer, fra første undersøgelse til hendes sorg og savn. Vægten er lagt på livet som patient og ægtefælle. Beskrivelsen afægteparrets møde med et - utvivlsomt nødvendigvis, men ikke hensigtsmæssigt fortravlet sygehusmiljø, afslører næsten ingen empatisk opmærksomhed, uanset at parret befinder sig imellem dødsdom og livshåb. Til beskrivelsens potentielle forebyggelsesgevinst hører også de lange interne ventetimer, og de hierarkisk skabte erfarings- og vidensniveauer: fra yngste hospitalsjunior og sidst til seniorskikkelsen.
Afstanden imellem liv-død-spørgsmålet og et vejledende svar gøres dermed hjerteknugende.

Rørende er børnebørnene, hvoraf drengen efter ventrikeloperationen siger: «Du har ingen mavesæk, farfar», hvortil hans lillesøster jublende tilføjer: «Men du har jo rygsæk!»

Datoer, knyttet til dødsfaldet, skaber erindringsblokeringer og uløselige passagemuligheder. Selv ønsket om at bevare den afdødes stemme i et indtalt mobiltelefonsvar viste sig teknisk umuligt, trods mange behjertede forsøg.

Alene bør indgå i sundhedsvæsenets uddannelsesprogrammer, så Kjersti Ericsson kan nå mange af dem, som er daglige aktører i liv og døds eksistentielle perspektiver.

\section{Povl Riis}

EldreForum

Odense C.

Danmark

\section{Perspektivrikt om Karolinska Institutet og amerikansk filantropi}

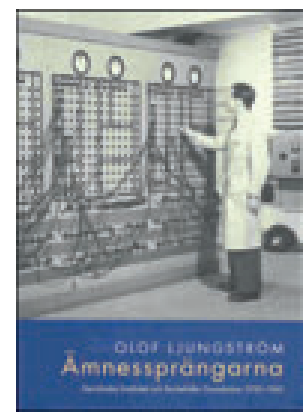

\section{Olof Ljungström \\ Ämnessprängarna}

Karolinska Institutet och Rockefeller

Foundation 1930-1945. 320 s, ill. Stockholm:

Karolinska Institutet University Press, 2010.

Pris SEK 225

ISBN 978-91-85565-40-5

Idéhistorikeren Olof Ljungström analyserer her perioden da Karolinska Institutet for alvor tok steget fra medisinsk lærested til i tillegg å bli internasjonalt anerkjent for sitt bidrag til eksperimentell medisinsk forskning. Hovedfokus ligger på hvordan fagmiljøene innen fysiologi og kjemi - og de stadig omdefinerte underliggende emner - ved instituttet ivaretok mulighetene som lå i relasjonen til den amerikanske filantropiske stiftelsen Rockefeller Foundation.

Boken inngår i en serie på ti utgivelser i forbindelse med instituttets 200-årsmarkering. Gjennom å analysere relasjonene mellom forskere ved instituttet og Rockefeller Foundations «officers» plasserer forfatteren utviklingen ved Karolinska Institutet mellom 1930-45 i en internasjonal sammenheng. En rekke problemstillinger av generell vitenskapshistorisk interesse blir berørt, men den primære målgruppen er likevel lesere med særlig glød for universitetshistorie, gjerne med en viss forhåndskunnskap om Karolinska Institutets ledende forskere.

Tittelen rommer flere betydninger som samlet danner det sentrale temaet. For det første at rammene for et vitenskapelig «ämne» utvikles gjennom ny kunnskap. Videre henspeiler tittelen på nukleinsyrene som sentralt forskningsobjekt, som til tross for den såkalte «proteinhypotesens» dominans ble ansett som avgjørende for «ämnesomsetningen» i cellekjernen. Den tredje betydningen er hvordan de medisinske «ämnen» som var vokst frem som undervisningsfag etter tysk forbilde, ble sprengt i møte med nye forskningspraksiser. De nye «eksperimentalistene» opplevde faggrensene som snevre, og nye konstellasjoner, infrastrukturer, publikasjonspraksiser og fagbenevnelser tvang seg frem på tvers av disiplinene. Utviklingen av begrepene «molekylær biologi», «medisinsk biofysikk» og en rekke andre sett $\mathrm{i}$ instituttet og Rockefellers kontekst er fascinerende nærstudier av vitenskap i endring.

Boken er inndelt i seks deler med kronologiske kapitler med ulikt tematisk fokus. Etter innledningen presenteres instituttets utvikling mellom første og andre verdenskrig. Neste kapittel intro- 